\title{
Restoration of Cytomegalovirus Antigen Presentation by Gamma Interferon Combats Viral Escape
}

\author{
HARTMUT HENGEL, ${ }^{1}$ PERO LUČIN, ${ }^{1}$ STIPAN JONJIĆ, ${ }^{2}$ THOMAS RUPPERT, ${ }^{1}$ \\ AND ULRICH H. KOSZINOWSKI ${ }^{1 *}$ \\ Department of Virology, University of Heidelberg, Im Neuenheimer Feld 324, D-69120 Heidelberg, Germany, ${ }^{1}$ and \\ Department of Physiology and Immunology, Faculty of Medicine, University of Rijeka, 51000 Rijeka, Croatia ${ }^{2}$
}

Received 10 June 1993/Accepted 12 October 1993

\begin{abstract}
An immediate-early protein of murine cytomegalovirus (MCMV), pp89, elicits an immunodominant and protective major histocompatibility complex (MHC) class I $\mathbf{L}^{d}$-restricted $\mathrm{CD8}^{+}$T-lymphocyte response. Remarkably, presentation of the naturally processed peptide of pp89, the nonapeptide YPHFMPTNL, is abolished during permissive MCMV infection in vitro. This defect in pp89 presentation is due to the expression of MCMV early gene functions that specifically block the transport of peptide-charged MHC class I complexes to the cell surface (M. Del Val, H. Hengel, H. Häcker, U. Hartlaub, T. Ruppert, P. Lučin, and U. H. Koszinowski, J. Exp. Med. 176:729-738, 1992). Here, we demonstrate that MCMV-specific CD8 ${ }^{+}$T lymphocytes can reconstitute pp89 presentation in a parakrine fashion. The lymphocytes mediate the restoration of antigen presentation by MCMV-infected cells by releasing gamma interferon (IFN- $\gamma$ ). IFN- $\gamma$ has no effect on synthesis and stability of the viral antigen pp89 nor does it interfere with the expression of viral early genes and their inhibitory effect on MHC class I molecule maturation. IFN- $\gamma$ results in a 25-fold increase in the synthesis of MHC class I molecules and a similar increase in the abundance of pp89-derived peptide. Many of the MHC molecules remain retained by the viral effect, but a surplus of MHC molecules escapes the effect and provides the effective surface presentation of the peptide. Adoptive cell transfer studies demonstrate the IFN- $\gamma$ dependence of $\mathrm{CD8}^{+}$T-lymphocyte function in vivo. Altogether, these data reconcile the paradoxical findings of an impaired pp89 presentation in vitro in parallel with pp89-specific $\mathrm{CD8}^{+}$T-cell protection in vivo. The results also imply a role of IFN- $\gamma$ in the T-lymphocyte-mediated control of cytomegalovirus infection. The known propensity of cytomegalovirus to cause serious disease in the immunocompromised host is discussed in the light of these findings.
\end{abstract}

Major histocompatibility complex (MHC) class I molecules bind peptides derived from endogenously synthesized proteins and present them at the cell surface to $C D 8^{+} \mathrm{T}$ lymphocytes. Processing of antigens involves protein degradation and transport to the endoplasmic reticulum for MHC binding. After infection with a virus, cells degrade viral proteins in the cytosol into short peptides of 8 to 11 amino acids in length $(38,42)$. For antigen processing in the cytosol, a nonlysosomal proteinase complex that contains MHC-encoded subunits is regarded as a candidate $(18,27,29)$. The translocation of peptides into the rough endoplasmic reticulum requires ATP-dependent peptide transporter proteins of the $A B C$ family $(31,41)$ or occurs independently of ATP (23). Binding of antigenic peptides to MHC class I heavy chains induces folding (43) and stable association with $\beta_{2} \mathrm{~m}(22,43)$ in the trimolecular MHC class I complex that is transported to the plasma membrane. MHC class I molecules lacking peptide have a different conformation and are deficient with respect to surface transport and stability $(15,25)$.

Cytomegalovirus (CMV) is a member of the herpesvirus family and establishes acute and chronic infections. After primary infection, CMV persists in the host for life in a latent state from which reactivation can occur. While infection of the immunocompetent host is usually asymptomatic, CMV causes severe and fatal disease in immunocompromised individuals $(11,14)$. MHC class I-restricted T lymphocytes play a crucial

\footnotetext{
* Corresponding author. Mailing address: Department of Virology, Institute for Hygiene, University of Heidelberg, Im Neuenheimer Feld 324, D-69120 Heidelberg, Germany. Phone: (49) 622156 3000. Fax: (49) 6221563104.
}

role in the host defense against CMV (21). This has been experimentally demonstrated in several studies, e.g., in a murine adoptive-transfer model in which specifically sensitized $\mathrm{CD}^{+} \mathrm{T}$ lymphocytes limit viral spread, prevent tissue destruction, and protect against lethal murine cytomegalovirus (MCMV) disease $(33,36)$. Vaccination with a recombinant vaccinia virus expressing the nonstructural immediate early (IE) protein pp89 of MCMV conferred protection against lethal infection in BALB/c $\left(H-2^{d}\right)$ mice by the induction of $\mathrm{CD}^{+} \mathrm{T}$ lymphocytes (16).

CMV gene expression is regulated in a cascade fashion characteristic of herpesviruses and can be subdivided into an IE, an early (E), and a late phase. Previous studies of MCMV have demonstrated that CMV interferes with MHC class I-dependent antigen presentation (8). Further analysis revealed that $E$ gene functions prevent the presentation of peptides derived from IE-expressed proteins by blocking the transport of the peptide-loaded MHC class I molecule $\mathbf{L}^{\mathbf{d}}$ through the Golgi compartment (7).

In this study, we set out to explain the apparent contradiction between the generation of the dominant and protective fraction of pp89-specific cytotoxic T lymphocytes (CTL) in vivo and the control of the virus over antigen presentation in vitro. We tested the recognition of MCMV-infected cells throughout all three phases of infection. Here, we report that cytokines produced by $\mathrm{MCMV}$-specific $\mathrm{CD}^{+} \mathrm{T}$ cells compensate the negative viral effect on antigen presentation. The major factor could be identified as gamma interferon (IFN- $\gamma$ ). Although this cytokine also has direct antiviral activities, the effect upon antigen presentation function is associated with the induction of MHC class I genes of the host. 


\section{MATERIALS AND METHODS}

Mice. BALB/cJ $\left(H-2^{d}\right)$ and B10.G $\left(H-2^{q}\right)$ mice were kept in our own colony under specific pathogen-free conditions.

Cells. Mouse embryo fibroblasts (MEF) prepared from both strains of mice were used after three in vitro passages for virus infections and extraction of naturally processed peptides.

Viruses. MCMV of the strain Smith (ATCC VR-194) was used as tissue culture-grown virus. The recombinant MCMV lac1, expressing the lac $Z$ gene encoding $\beta$-galactosidase as an IE gene, has been described before (7).

Reagents and antibodies. Recombinant murine IFN- $\gamma$ was kindly provided by G. R. Adolf, Bender Vienna, Vienna, Austria. The specific activity of recombinant IFN- $\gamma($ IFN- $\gamma$ ) (lot M3-RD48) was $10^{7} \mathrm{U} / \mathrm{mg}$, as determined by the encephalomyocarditis virus bioassay on L cells. The following monoclonal antibodies (MAbs) were used: 28-14-8S (anti- $\mathrm{L}^{\mathrm{d}} \alpha 3$ ) (ATCC HB 27), 64-3-7 (anti- $L^{d} \alpha 2$, selective for $L^{d}$ alt) (24), 30-5-7 (anti- $L^{\mathrm{d}} \alpha 2$, selective for $\beta_{2}$ m-associated $L^{\mathrm{d}}$ ) (24), 345-8S (anti-D ${ }^{\mathrm{d}}$ ) (ATCC HB 102), GK1.5 (anti-CD4) (ATCC TIB 207), YTS-169.4 (anti-CD8) (6), YTS-191.1 (anti-CD4 ${ }^{+}$) (6), R4-6A2 (anti-murine IFN- $\gamma$ ) (ATCC HB 170), AN-18 (anti-murine IFN- $\gamma$ ) (32); and V1q (anti-murine tumor necrosis factor) (12). Anti-MCMV serum was collected from latently infected $B A L B / c$ mice. The peptide antiserum $b 5 / 1$ has been described previously (10). Rabbit anti-murine IFN- $\beta$ antibodies were purchased from Paesel and Lorei (Frankfurt/Main, Germany), and purified rat immunoglobulin $G$ was from Dianova (Hamburg, Germany). Low Tox rabbit complement was from Cedarlane Laboratories (Hornby, Ontario, Canada).

Infection conditions. Restriction of MCMV gene expression to the IE phase was achieved by infecting cells in the presence of cycloheximide $(\mathrm{CH})(50 \mu \mathrm{g} / \mathrm{ml})$, which was replaced $3 \mathrm{~h}$ later by actinomycin D (actD) $(5 \mu \mathrm{g} / \mathrm{ml})$. Conditions of controlled early gene expression were achieved by infection of cells in the presence of $\mathrm{CH}$ for $3 \mathrm{~h}$ before $\mathrm{CH}$ was washed out and actD was added after a 90 -min period free of metabolic inhibitors. IE proteins translated in this period activate the transcription of $\mathrm{E}$ genes until actD blocks further transcription. In some experiments, actD was added at the indicated time point after infection to prevent further viral gene expression. Late-phase gene expression was prevented by the use of phosphonoacetic acid $(250 \mu \mathrm{g} / \mathrm{ml})$, which arrests MCMV-infected cells in the E phase. In all experiments, cells were infected with a multiplicity of infection of 0.3 , and the infection was performed by centrifugation at $800 \times g$ for $30 \mathrm{~min}$, in order to enhance the efficiency by a factor of 20 .

Isolation of endogenously processed peptides. After trypsinization, washing, and counting of cells, peptides were extracted with trifluoroacetic acid from whole cell lysates $\left(\sim 4 \times 10^{7}\right.$ cells) and separated first by size on a Sephadex G-25 column and subsequently on a reverse-phase high-pressure liquid chromatography (HPLC) column. Collected fractions were lyophilized and tested after resuspension in medium with pp89-specific CTL in a standard ${ }^{51} \mathrm{Cr}$-release assay as described previously $(7,9)$.

Cytolytic assays. Target cells were trypsinized and labeled for 90 min with $\mathrm{Na}_{2}{ }^{51} \mathrm{CrO}_{4}$, and a standard 4-h cytolytic assay was performed with $10^{3}$ target cells and graded numbers of effector cells in fivefold dilution steps. Data represent the mean percentage of specific lysis from three replicate cultures. HPLC fractions to be tested were lyophilized and resolved in culture medium before labelled P815 cells were incubated for $1 \mathrm{~h}$ at $37^{\circ} \mathrm{C}$ and cytolytic effector cells were added.

ELISA for determination of IFN- $\boldsymbol{\gamma}$. IFN- $\gamma$ was detected in a standard sandwich enzyme-linked immunosorbent assay
(ELISA) with the help of the anti-murine IFN- $\gamma$-specific MAb R4-6A2 as a capture antibody in conjunction with biotinylated $\mathrm{AN}-18 \mathrm{MAb}$ (32). Optical density values were measured in duplicates and converted to units per milliliter according to a standard curve obtained with recombinant murine IFN- $\gamma$.

Metabolic labeling, immunoprecipitation, and endoglycosidase $\mathbf{H}$ treatment. Cells were labeled with $\left[{ }^{35} \mathrm{~S}\right]$ methionine $(1,200 \mathrm{Ci} / \mathrm{mmol}$; Amersham, Braunschweig, Germany) at a concentration of $500 \mu \mathrm{Ci} / \mathrm{ml}$ as described previously (7). In brief, quantitative precipitations were performed sequentially with ascitic fluids of the MAb 64-3-7, followed by 28-14-8S and 34-5-8S. To assure quantitative retrieval of immune complexes, the lysates were incubated two more times with protein A-Sepharose (Pharmacia, Freiburg, Germany) before addition of the next MAb. Immune complexes were mock treated or digested with $2 \mathrm{mU}$ of endoglycosidase $\mathrm{H}$ (Endo $\mathrm{H}$ ) (Boehringer, Mannheim, Germany) overnight at $37^{\circ} \mathrm{C}$, eluted with sample buffer, and analyzed by 10 to $15 \%$ polyacrylamide gradient gel electrophoresis. The gels were treated with En ${ }^{3}$ Hance (NEN-Dupont, Boston, Mass.), dried, and exposed to $\mathrm{X}$-Omat $\mathrm{AR}$ films at $-70^{\circ} \mathrm{C}$ for 1 to 7 days.

Adoptive transfer experiments. In vivo depletion of $\mathrm{CD}^{+} \mathrm{T}$ lymphocytes in thymectomized donor mice was carried out as described elsewhere $(26,36)$. In brief, depletion was started by intravenous treatment with anti-CD4 MAb at a dose of $1 \mathrm{mg}$ for 3 successive days. A single antibody injection was repeated every 7 days. For short-term depletion of $\mathrm{CD}^{+} \mathrm{T}$ lymphocytes in adoptive transfer recipients, mice were injected intraperitoneally with $1 \mathrm{mg}$ of anti-CD8 MAb every 4th day, starting $1 \mathrm{~h}$ after infection and cell transfer. In vivo neutralization of IFN- $\gamma$ was achieved by the injection of $1 \mathrm{mg}$ of R4-6A2 MAb for 2 successive days starting from the day of infection. Thereafter, injections of $1 \mathrm{mg}$ of R4-6A2 were repeated every 3rd day (26). The prophylactic adoptive cell transfer was performed as described elsewhere (36). Recipient mice were immunodepleted by total-body gamma-irradiation of 6 Gy delivered as a single dose. At $2 \mathrm{~h}$ after irradiation and infection with $2 \times 10^{5}$ PFU of MCMV, $2 \times 10^{5}$ spleen lymphocytes from donor mice were infused into the tail vein. Experiments were terminated 2 weeks after cell transfer, and virus titers in tissues of recipients were determined.

\section{RESULTS}

Absence of antigen presentation of pp89 during the MCMV replication in vitro. Selective and enhanced expression of MCMV IE genes results in the presentation of the peptide YPHFMPTNL derived from MCMV IE protein pp89 by the MHC class I molecule $\mathrm{L}^{\mathrm{d}}(8,9)$ (Fig. 1F). However, a 90-min period of viral $E$ gene expression suffices to prevent antigen presentation of pp89, as shown before (8) and demonstrated in Fig. 1G. In order to define the stages of pp89 presentation during permissive MCMV infection, infected target cells were tested with peptide-specific CTL throughout the MCMV replication cycle. As expected, the natural course of MCMV infection was associated with inhibited pp89 presentation at times of E gene expression 6 or $16 \mathrm{~h}$ postinfection. (Fig. $1 \mathrm{C}$ and D). However, in agreement with previous experiments (8) that indicated at best marginal antigen presentation very early or very late, pp89 peptides were not detectable within the first 90 min of infection (see Fig. 1B) nor after $24 \mathrm{~h}$ of infection representing the late phase of infection (Fig. 1E). The virtual absence of pp89 presentation was also observed during the course of permissive infection when investigated in another $\mathrm{H}-2$ haplotype, $\mathrm{H}-2^{q}$ (data not shown). At the same time as when antigen presentation of pp89 was abolished, other 

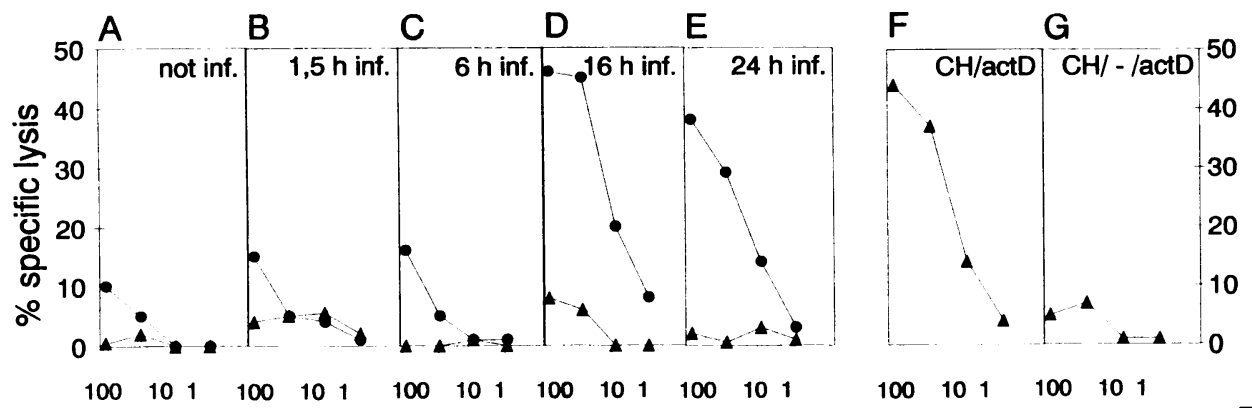

FIG. 1. Absence of pp89 presentation during permissive MCMV infection. Presentation of pp89 peptides was tested by pp89-specific BALB/c CTL (triangles) on MEF cells infected with MCMV for the indicated times before actD was added (A to E) to prevent further viral gene expression. Subsequently, cells were harvested and labelled for $90 \mathrm{~min}$ with ${ }^{51} \mathrm{Cr}$ before being assayed in a 4-h standard chromium release assay with graded numbers of effector cells. In parallel, targets were incubated with MCMV-polyspecific BALB/c CTL (circles). Infection was performed in the presence of $\mathrm{CH}$, which was replaced after $3 \mathrm{~h}$ by actD to achieve enhanced and selective IE protein synthesis $(\mathrm{F})$. Infection was performed in the presence of $\mathrm{CH}$, which was washed out after $3 \mathrm{~h}$, allowing IE protein synthesis, followed by subsequent $\mathrm{E}$ gene transcription and translation. The transcription of viral genes was terminated after $90 \mathrm{~min}$ by the addition of actD $(\mathrm{G})$. E/T, effector-to-target cell ratio.

MCMV antigens that are not defined in molecular terms escaped the $E$ gene effect and could be detected by polyspecific CTL during the later phases of infection at 16 and $24 \mathrm{~h}$ postinfection (Fig. 1D and E) $(8,34)$. Recognition of pp89 in cells arrested for selective IE gene expression due to abortive infection could perhaps explain the generation of pp89-specific CTL in vivo. However, this does not explain the established capacity of pp89-specific CTL to control productive infection in vivo (36). We therefore concluded that the lack of presentation in vitro cannot reflect the conditions that govern pp89 presentation in vivo.

$\mathrm{CD8}^{+}$T-cell-derived IFN- $\gamma$ restores $\mathrm{pp89}$ presentation. pp89-specific CTL dominate among polyspecific MCMV-specific $T$ cells in vivo (35) as well as in vitro after restimulation of primed splenocytes with MCMV (unpublished observation). From these observations, we hypothesized that a regulatory mechanism that compensates the inhibitory $E$ gene effect and provides pp89 recognition must exist. We reasoned that lymphocytes or monocytes in infected tissues could contribute to antigen presentation by factor release. In search of such factors, target cells were incubated with conditioned medium derived from MCMV-specific T-cell cultures prior to infection with MCMV. Remarkably, target cells treated that way now presented $\mathrm{pp} 89$ antigen during the $\mathrm{E}$ phase of virus replication (Fig. 2, right panel) to an extent comparable with that of cells infected under IE conditions (Fig. 2, left panel). The same was true for the presentation of another antigen, $\beta$-galactosidase, when expressed as an IE gene from the recombinant MCMV lac1 (7) (data not shown). In order to identify the soluble factor(s) responsible for the compensation of the viral effect, neutralizing antibodies for several cytokines were used. The MAb R4-6A2 neutralizing IFN- $\gamma$ abrogated the capacity of the T-cell-conditioned supernatant to restore pp89 recognition by CTL (Fig. 2, right panel). This identified IFN- $\gamma$ as an important factor or cofactor for pp89 antigen presentation during permissive infection.

Previous in vivo studies have revealed that the $\mathrm{CD} 8^{+} \mathrm{T}$-cell subset is able to control MCMV infection autonomously (17, 33 ). To determine the capacity of $\mathrm{CD}^{+} \mathrm{T}$ cells to produce IFN- $\gamma$ in vitro, lymphocytes generated in MCMV-specific T-cell cultures were harvested, depleted of either the $\mathrm{CD}^{+}$or the $\mathrm{CD} 8^{+} \mathrm{T}$-cell subset, and incubated with MCMV-infected fibroblasts for $6 \mathrm{~h}$ before the IFN- $\gamma$ content in the supernatants was measured in a sandwich ELISA. As detailed in Table 1, up to $85 \mathrm{U}$ of IFN- $\gamma$ per ml were produced within $6 \mathrm{~h}$ and depletion of $\mathrm{CD}^{+} \mathrm{T}$ cells abrogated the production of IFN- $\gamma$, whereas the removal of $\mathrm{CD} 4^{+} \mathrm{T}$ cells had no effect. These data identified MCMV-antigen-specific $\mathrm{CD}^{+}{ }^{+} \mathrm{T}$ cells as a major source of IFN- $\gamma$ under the experimental conditions chosen.

Kinetics of the restored pp89 presentation function by rIFN- $\boldsymbol{\gamma}$. We tested whether IFN- $\boldsymbol{\gamma}$ could mediate the effect on its own or whether the synergistic action required further cytokines in the T-cell-conditioned supernatant. As depicted in Fig. 3, preincubation with recombinant IFN- $\gamma$ resulted in $p p 89$ antigen presentation in a dose-dependent manner. In comparison with MCMV-infected cells restricted to IE gene expression, $20 \mathrm{U}$ of rIFN- $\gamma$ per ml fully compensated the MCMV E gene effect and even at $0.2 \mathrm{U} / \mathrm{ml}$ showed a marginal effect. The same results were obtained when pp89 peptides were presented by another class I molecule, $\mathrm{L}^{\mathrm{q}}$ (data not shown). In cells arrested for IE expression, antigen presentation was only slightly improved by IFN- $\gamma$. Studies on the kinetics of the IFN- $\gamma$ effect revealed that for the restoration of antigen presentation a preincubation of cells for $12 \mathrm{~h}$ was the minimum

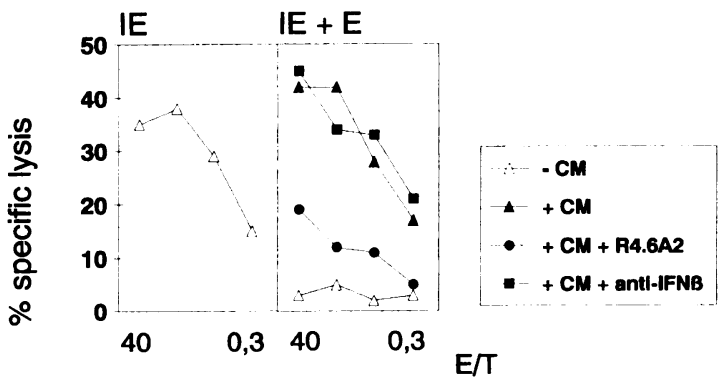

FIG. 2. Restoration of pp89 presentation by supernatant from MCMV-specific T-cell cultures. At $48 \mathrm{~h}$ before MCMV infection, conditioned medium (CM) from MCMV-polyspecific T-cell cultures propagated for 4 weeks was transferred on MEF together with anti-IFN- $\gamma$ MAb R4-6A2 (R4.6A2) or with polyclonal rabbit antimouse IFN- $\beta$ or without antibodies. Target cells were infected as described in Materials and Methods. Presentation of pp89 peptides was determined in a chromium release assay using graded numbers of pp89-specific CTL. IE, restriction of MCMV gene expression to the IE phase; IE $+E$, conditions of controlled early gene expression. E/T, effector-to-target cell ratio. 
TABLE 1. IFN- $\gamma$ production by MCMV-specific T lymphocytes ${ }^{\star}$

\begin{tabular}{|c|c|c|c|}
\hline \multirow{2}{*}{$\begin{array}{l}\text { Infection condition } \\
\text { of target cells" }\end{array}$} & \multicolumn{3}{|c|}{$\begin{array}{c}\text { IFN- } \gamma \text { productionc with indicated treatment of } \\
\text { T lymphocytes }\end{array}$} \\
\hline & None & $\begin{array}{l}\text { Anti-CD8 + } \\
\text { complement }\end{array}$ & $\begin{array}{l}\text { Anti-CD4 + } \\
\text { complement }\end{array}$ \\
\hline Mock & 2 & 0.5 & 1.8 \\
\hline IE & 85 & 2.5 & 65 \\
\hline $\mathrm{E}^{d}$ & 80 & 8 & 80 \\
\hline Late & 70 & 4 & 80 \\
\hline
\end{tabular}

${ }^{a} \mathrm{~T}$ lymphocyte cultures $\left(7.5 \times 10^{6}\right.$ cells $)$ from MCMV-primed BALB/c micc were restimulated weekly with MCMV in vitro and allowed to rest for 3 weeks. Before being measured for IFN- $\gamma$ production, harvested cells were washed and at $5 \times 10^{5}$ cells per well were treated with either purified anti-CD8 MAb YTS-169.4 plus complement or anti-CD4 MAb GK1.5 plus complement before being incubated with $10^{5} \mathrm{MCMV}$-infected or mock-infected MEF in $0.25 \mathrm{ml}$ of medium. After $6 \mathrm{~h}, 0.15 \mathrm{ml}$ of the supernatant was removed and IFN- $\gamma$ was determined by a sandwich ELISA.

${ }^{b} \mathrm{BALB} / \mathrm{c}$ MEF were infected with MCMV as described in Materials and Methods.

'In units per milliliter.

${ }^{d}$ Phosphonoacetic acid was used to arrest gene expression in the E phase.

and $48 \mathrm{~h}$ of pretreatment represented the optimum (Fig. 4). Two conclusions were drawn: first, that IFN- $\gamma$ alone is able to mediate the effect; and second, that IFN- $\gamma$ cannot restore antigen presentation in already-infected cells.

IFN- $\gamma$ does not inhibit viral $E$ gene expression. IFN- $\gamma$ displays multiple effects on viral as well as cellular genes (30, 44). To find out whether IFN- $\gamma$ acts on antigen presentation by affecting either viral $\mathrm{E}$ or cellular genes or both, the synthesis of $\mathrm{E}$ proteins in IFN- $\gamma$-conditioned cells was tested. The MCMV E-phase factor responsible for the intracellular retention of correctly assembled MHC class I complexes (7) is not yet identified. As markers, a set of viral $E$ proteins was precipitated with MCMV antiserum from E-phase-infected cells pretreated with IFN- $\gamma$ or not and analyzed by sodium dodecyl sulfate-polyacrylamide gel electrophoresis (SDSPAGE). As demonstrated in Fig. 5, the precipitated proteins included the 36- and $38-\mathrm{kDa}$ E1 proteins encoded by the transcription unit e1 (4). e1 is under control of the same IE genes and is transcribed simultaneously with the E gene(s) that prevent pp89 presentation (unpublished observation). The pattern of polypeptides induced after IFN- $\gamma$ incubation revealed no principal differences, although subtle alterations in protein synthesis and stability of the E1 polypeptides were

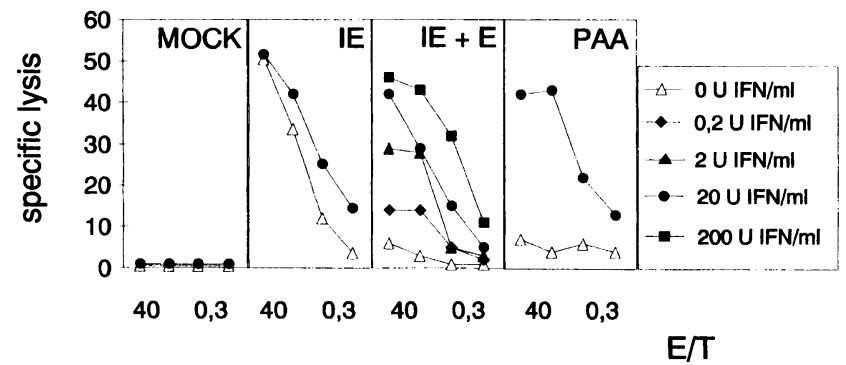

FIG. 3. rIFN- $\gamma$ restores pp 89 presentation dose dependently. Target cells were incubated with different doses of rIFN- $\gamma$ for $48 \mathrm{~h}$. After infection and expression of MCMV E genes, presentation of pp89 was tested in a cytolytic assay using graded numbers of pp89-specific CTL. Phosphonoacetic acid (PAA; $250 \mu \mathrm{g} / \mathrm{ml}$, right panel) prevents latephase gene expression, thereby arresting MCMV-infected cells in the E phase. IE and IE + E are defined as for Fig. 2. E/T, effector-to-target cell ratio.

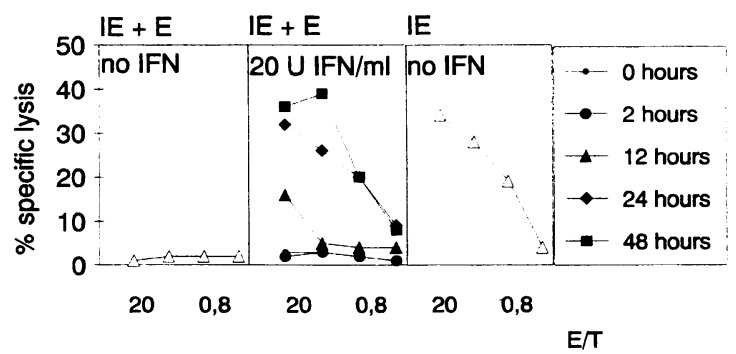

FIG. 4. For antigen presentation, IFN- $\gamma$ treatment of cells must precede MCMV infection. Presentation of pp89 antigen was determined after different incubation periods with $20 \mathrm{U}$ of IFN- $\gamma$ per $\mathrm{ml}$ prior to infection of cells with MCMV under conditions permissive for E gene expression (middle panel). Untreated target cells expressing IE plus $E$ or, selectively, IE genes were used as controls (left and right panels, respectively). E/T, effector-to-target cell ratio.

noted (Fig. 5). A potential effect on pp89 synthesis or stability was excluded from pulse-chase experiments (data not shown).

Effect of IFN- $\gamma$ on peptide processing. During permissive MCMV infection, processing of pp89 to peptide is unabated but presentation is prevented (7). We studied whether the amount of processed antigenic peptides is altered with respect to peptide quality and quantity in IFN- $\gamma$-treated E-phaseexpressing cells. The analysis of endogenous pp89 peptides after acidic extraction and reverse-phase HPLC separation revealed no qualitative differences upon IFN- $\gamma$ pretreatment (Fig. 6A). Consistently, the biological activity was contained in two antigenic peaks in fractions 25 and 27-28 of our HPLC separation. Fraction $27-28$ represents the nonamer peptide

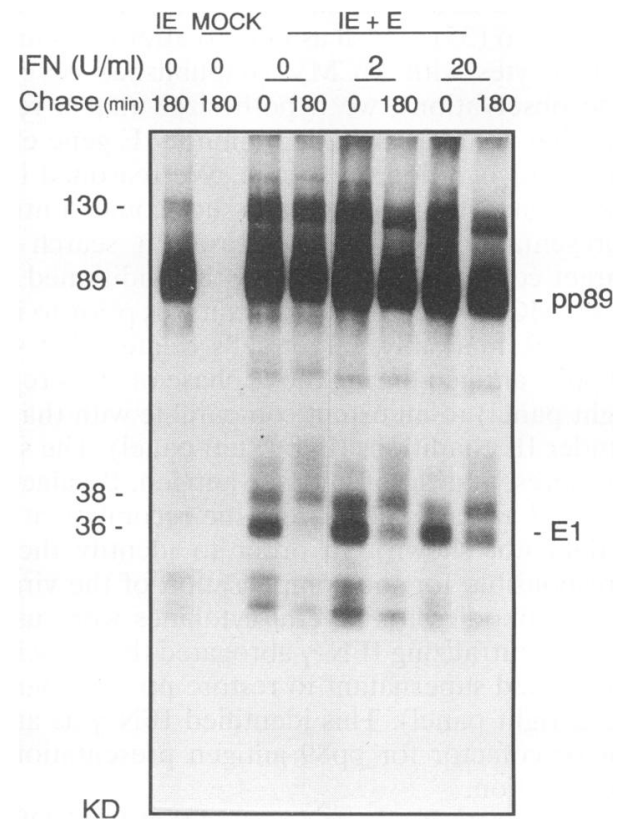

FIG. 5. IFN- $\gamma$ does not inhibit viral E gene expression. Synthesis and stability of viral proteins in IFN- $\gamma$-pretreated cells were determined by metabolic labelling of infected cells with $\left[{ }^{35} \mathrm{~S}\right]$ methionine for 90 min starting $3 \mathrm{~h}$ postinfection and chasing for the time indicated, followed by immunoprecipitation of cell lysates with anti-MCMV serum and analysis by SDS-PAGE. The positions of the IE1 protein pp 89 and the E1 proteins of 36 and $38 \mathrm{kDa}$ are indicated. IE and IE + $\mathrm{E}$ are defined as for Fig. 2. 

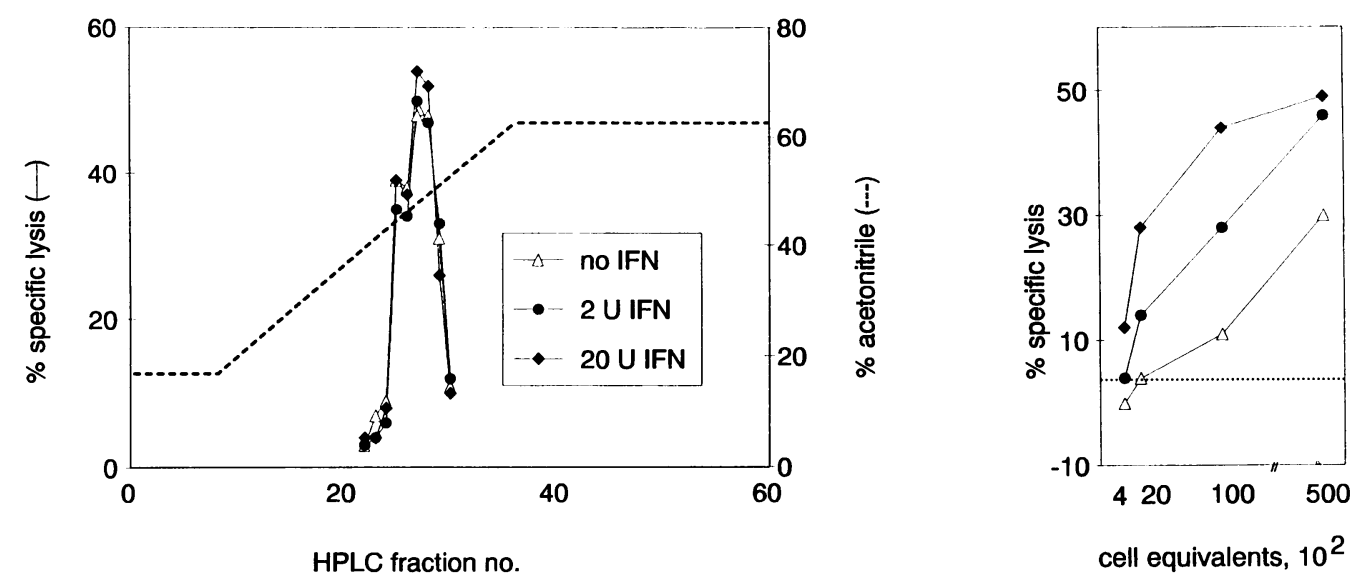

FIG. 6. Absence of qualitative changes in pp 89 processing but an increase in pp 89 peptide yield by IFN- $\gamma$. (A) After a 48-h exposure with IFN- $\gamma$, $\mathrm{BALB} / \mathrm{c}$ MEF were infected with MCMV under IE-plus-E conditions. At $10 \mathrm{~h}$ postinfection acid-soluble molecules were extracted and separated by size exclusion chromatography, followed by reverse-phase HPLC using the indicated acetonitrile gradient for elution. HPLC fractions were tested in triplicates with pp89-specific CTL for their content of antigenic peptides. (B) The antigenic peptides in peak fraction 27 were quantified by testing serial dilutions in the ${ }^{51} \mathrm{Cr}$-release assay. The calculated number of infected cells from which peptides were recovered is given on the horizontal axis. The detection limit of pp89 peptides by CTL in this experiment is indicated as a dotted line. The symbols are defined as for panel A.

sequence YPHFMPTNL (9). Notably, however, the serial dilution of the peak fraction 27 revealed a 25 -fold higher amount of the peptide in cells incubated with $20 \mathrm{U}$ of IFN- $\gamma$ per $\mathrm{ml}$ (Fig. 6B). The increase implied an enhancement of pp89 processing to the finally trimmed peptide, or an increased stability of the peptide, or both. Although the peptide yield was considerably higher, the amount and stability of the antigenic protein $\mathrm{pp} 89$ remained constant under conditions positive or negative for antigen presentation (data not shown). This observation indicates that it is not the amount of the viral protein which represents the limiting factor during antigen presentation.

IFN- $\gamma$ induces overexpression of MHC class I molecules without changing $\mathbf{L}^{\mathbf{d}}$ conformation. The MHC class I heavychain $\mathrm{L}^{\mathrm{d}}$ exists in conformations that differ in terms of protein folding, $\beta_{2} \mathrm{~m}$ association, peptide binding, and intracellular transport $(24,40)$. Since $90 \%$ of all $\mathrm{L}^{\mathrm{d}}$ molecules in MEF belong to the $\beta_{2} \mathrm{~m}$ free-heavy-chain species, termed $\mathrm{L}^{\mathrm{d}}$ alt $(40)$, we wondered whether IFN- $\gamma$ shifts the ratio of the $L^{\mathrm{d}}$ conformations in favor of $\beta_{2}$ m-associated heavy chains. IFN- $\gamma$ has been reported to induce the association of MHC class I heavy chains with $\beta_{2} \mathrm{~m}$ in MHC class I-deficient tumor cells which express constitutively unassembled heavy chains $(19,39)$. Quantitative immunoprecipitations after $\left[{ }^{35}\right.$ S $]$ methionine pulse-labelling of IFN- $\gamma$-preincubated E-phase-expressing cells demonstrated a strong increase of $\beta_{2} \mathrm{~m}$-assembled $\mathrm{L}^{\mathrm{d}}$ heavy chains (Fig. 7A, right panel), which corresponded to a factor of 20 to 30 in cytofluorometric analysis (data not shown), and also of $\mathrm{L}^{\mathrm{d}}$ alt molecules (Fig. 7A, left panel). Yet, IFN- $\gamma$ did not alter the ratio and the stability of the two forms either at $180 \mathrm{~min}$ of chase (Fig. 7A) or at later time points (data not shown) but led to a strong induction of both MHC class I conformations. From these data, we conclude that the IFN- $\gamma$ dependent pp89 presentation by $\mathrm{L}^{\mathrm{d}}$ was not due to a redistribution of $\mathrm{L}^{\mathrm{d}}$ alt heavy chains to correct assembled ternary $\mathrm{L}^{\mathrm{d}}$ complexes.

Establishment of MHC class I transport by IFN- $\boldsymbol{\gamma}$. The failure to present pp89 peptides under conditions of $\mathrm{E}$ gene expression (Fig. 1G) is caused by a retention of nascent assembled trimolecular MHC class I complexes within the constitutive secretory pathway. This is reflected by the sustained Endo H-sensitive phenotype of the N-linked carbohydrate moieties of the MHC class I glycoproteins (7). Since Endo $\mathrm{H}$ resistance is acquired by further modifications of the glycan structure that are catalyzed by enzymes in the medialGolgi apparatus (20), the blockade is located proximate to this compartment. In order to analyze the rate of intracellular MHC class I transport, metabolically labelled $\mathrm{L}^{\mathrm{d}}$ molecules were precipitated in a conformation-specific manner and subjected to Endo $\mathrm{H}$ digestion. MCMV-infected cells express low amounts of $L^{\mathrm{d}}$ alt molecules as well as $\mathrm{L}^{\mathrm{d}}-\beta_{2} \mathrm{~m}$ complexes (Fig. 7). Nearly all of the $L^{d}$ alt, and, because of the viral transport inhibition, also most of the $L^{d}-\beta_{2} m$ (Fig. 7A) as well as $D^{d}-\beta_{2} m$ (Fig. 7B) complexes were still in an Endo H-susceptible state after $180 \mathrm{~min}$ of chase. Conditioning of cells by IFN- $\gamma$ led to a strong increase in the synthesis of $\mathrm{L}^{\mathrm{d}}$ molecules. Associated with the higher amount of $\mathrm{L}^{\mathrm{d}}$ molecules was the emergence of Endo H-resistant forms. Results of essentially the very same type were found for $D^{d}-\beta_{2} m$ complexes (Fig. 7B). Note that in spite of the increase in class $I$ exit the majority of the complexes were still retained in the endoplasmic reticulumcis-Golgi, as indicated by an Endo $\mathrm{H}$-sensitive state (Fig. 7A and B). Therefore, the majority of Endo $\mathrm{H}$-sensitive class I complexes were still retained as a result of the MCMV E gene function.

The restoration of antigen presentation therefore comprises two events. One is the overexpression of class I molecules, which is associated with a higher load of antigenic peptides. In consequence, a fraction of peptide-loaded MHC molecules escapes the activity of the viral factor, acquires Endo $\mathrm{H}$ resistance, and is transported to the cell surface to present the peptides to CTL.

Neutralization of IFN- $\gamma$ prevents the antiviral effector function of $\mathrm{CD8}^{+} \mathrm{T}$ cells in vivo. The results described above predict that IFN- $\gamma$ should act as a cofactor for $\mathrm{CD}^{+} \mathrm{T}$ lymphocyte recognition also in vivo. To address this possibility, 

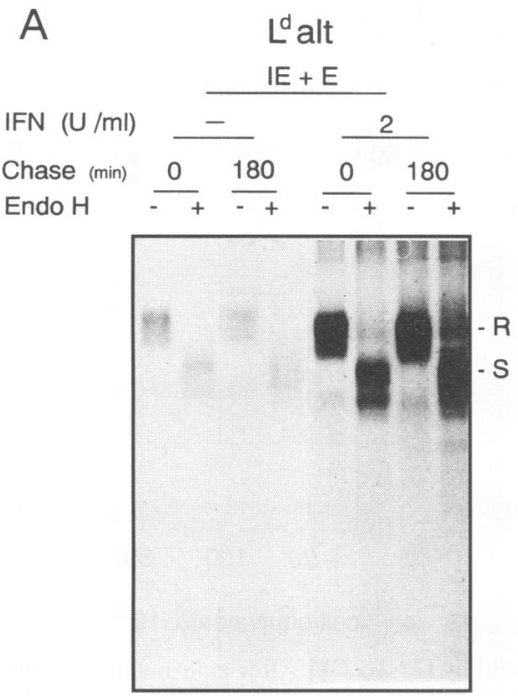
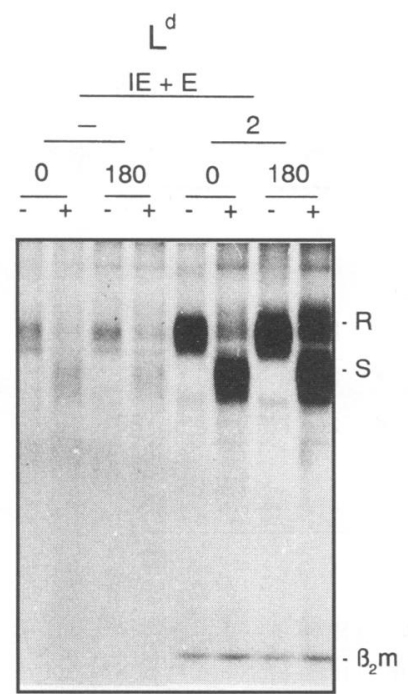

B
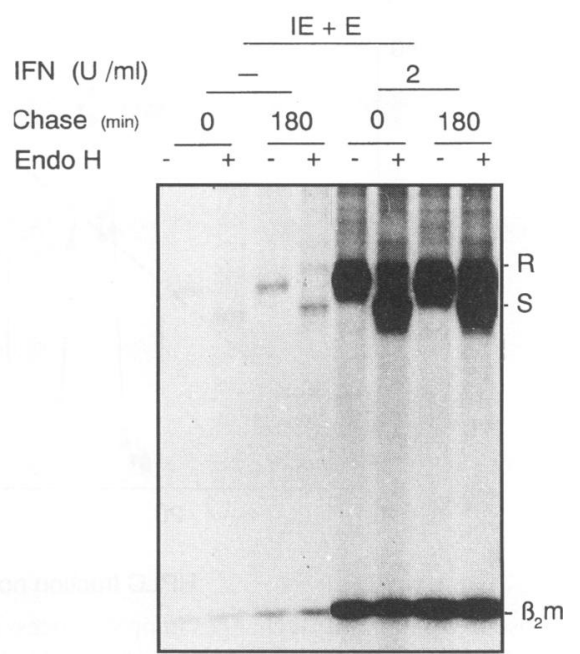

FIG. 7. (A and B). IFN- $\gamma$-induced overexpression of MHC class I molecules does not change the ratio of alternative $\mathrm{L}^{\mathrm{d}}$ conformations but restores the defective transport of MHC complexes through the medial-Golgi compartment. MCMV-infected cells were treated with CH and actD as described in Materials and Methods. After removal of $\mathrm{CH}$, cells were pulse-labelled with [ $\left.{ }^{35} \mathrm{~S}\right]$ methionine for 90 min and then chased for 180 min. Immunoprecipitations were performed sequentially first with the MAb 64-3-7 ( $\mathrm{L}^{\mathrm{d}}$ alt; panel A, left side), then with the MAb 28-14-8S ( ${ }^{\mathrm{d}}$; panel A, right side), and finally with the MAb 34-5-8S ( $\mathrm{D}^{\mathrm{d}}$; panel $\mathrm{B}$ ). Before gel electrophoresis, the +-marked samples were subjected to Endo $\mathrm{H}$ digestion. The forms resulting from enzymatic cleavage are indicated on the right with $\mathrm{S}$ (for susceptible) or $\mathrm{R}$ (for resistant).

an adoptive cell transfer model was used that measures the antiviral activity of transferred lymphocytes in MCMV-infected recipients immunodepleted by 6-Gy total-body gammairradiation. A previous study has demonstrated the $\mathrm{CD}^{+}$ T-lymphocyte subset as a source of IFN- $\gamma$ production during MCMV-infection in vivo (26). To exclude $\mathrm{CD} 4^{+} \mathrm{T}$-cell-derived IFN- $\gamma$ as a substitute for this $\mathrm{CD} 8^{+} \mathrm{T}$-cell function, donor mice were thymectomized and long-term depleted of $\mathrm{CD}^{+} \mathrm{T}$ cells. As depicted in Fig. 8, MCMV-primed donor cells limited productive virus infection in tissues which are critical in CMV disease $(33,37)$, namely, the lungs and the adrenal glands. As expected, depletion of the $\mathrm{CD} 8^{+} \mathrm{T}$-lymphocyte subset, the principal effector cell population in the adoptive transfer recipients, abrogated the clearance function. Remarkably, a similar loss of virus control resulted also from the neutralization of IFN- $\gamma$. IFN- $\gamma$ has a rather limited direct antiviral activity in vivo $(26)$ and cannot replace $\mathrm{CD} 8^{+}$effector cells when administered in vivo (15a). These results are consistent with the hypothesis that the IFN- $\gamma$ effect on antigen presentation is of relevance also in vivo.

\section{DISCUSSION}

In response to infection with $\mathrm{MCMV}, \mathrm{BALB} / \mathrm{c}$ mice generate $\mathrm{MHC}$ class I-restricted protective $\mathrm{CD}^{+} \mathrm{T}$ lymphocytes (36). These cells can operate independently of $\mathrm{CD} 4^{+} \mathrm{T}$ cells (33) and recognize predominantly the IE protein pp89-derived peptide YPHFMPTNL, which is presented by the MHC class I molecule $\mathrm{L}^{\mathrm{d}}(9,35)$. Analysis of pp89 presentation in vitro revealed that viral $\mathrm{E}$ genes abolish presentation of defined MCMV IE antigens including pp89 without affecting resident MHC class I molecules at the cell surface (8). The inhibitory mechanism is caused by an interference by $\mathrm{E}$ gene products with the transport of newly assembled and peptide-loaded MHC class I molecules through the Golgi compartment. At later steps of infection, this results in a strong reduction of surface-expressed class I molecules (7). Whether the later

\begin{tabular}{|c|c|c|c|c|}
\hline \multicolumn{5}{|c|}{ CD 4 - depleted donors } \\
\hline honprimed & MCMV-prime & & nonprimed & MCMV-primed \\
\hline \multicolumn{5}{|c|}{ treatment of recipients } \\
\hline$\varnothing$ & $\varnothing \quad \alpha C D 8 \quad \alpha$ & $\alpha \mathrm{IFN}-\gamma$ & $\varnothing$ & $\varnothing \alpha$ CD8 $\alpha$ IFN- $\gamma$ \\
\hline \multicolumn{3}{|c|}{ lungs } & \multicolumn{2}{|c|}{ adrenal glands } \\
\hline
\end{tabular}

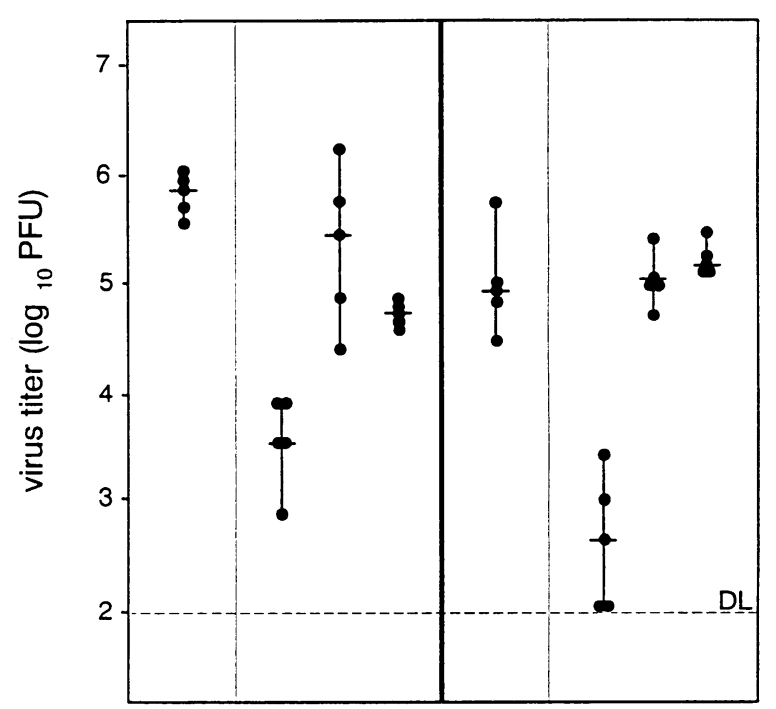

FIG. 8. The antiviral function of adoptively transferred $\mathrm{CD}^{+} \mathrm{T}$ cells requires endogenous IFN- $\gamma$. The virus clearance by $2 \times 10^{5}$ adoptively transferred lymphocytes from MCMV-primed, long-term $\mathrm{CD}^{+}{ }^{+}$-depleted mice in individual MCMV-infected irradiated recipients was compared. Recipient mice were treated with anti-CD8 MAb $(\alpha \mathrm{CD} 8)$, anti-IFN- $\gamma(\alpha$ IFN- $\gamma)$, or rat IgG $(\varnothing)$ as described in Materials and Methods. Organ titers determined 2 weeks after lymphocyte transfer from individual mice (circles) and median values (horizontal bars) are indicated. DL, detection limit. 
effects in surface MHC expression are solely due to the block of egress or whether the time of surface residence is also reduced is not yet known.

In this report, we extend previous findings and provide a rational explanation of why, despite a lack of pp89 antigen presentation by infected cells in vitro, $\mathrm{CD}^{+}$cells with specificity for this antigen are nevertheless generated and have protective properties in vivo $(16,36)$.

To solve this paradox, it was necessary to maintain that either antigen presentation in certain cell types is resistant to the viral effect, or that the degree of inhibition is subject to regulation, or both. Here, we have studied the second alternative and report that IFN- $\gamma$ can rescue the antigen presentation function from the inhibitory effect. We find that although active at several steps of the processing and presentation pathway, the pivotal activity of IFN- $\gamma$ is to mediate the export of peptide-loaded class I molecules to the cell surface. The major new information is that a cytokine can effectively oppose the evasion potential of a virus.

The first alternative, that some cells may be constitutively resistant to the viral effect, is still not excluded by these observations. In fact, particular cell types are able to present pp89 peptide constitutively during permissive infection in vitro (13a). However, antigen presentation by certain cells cannot explain all in vivo findings. Although cells resistant to the $\mathrm{E}$ gene effect may suffice to initiate a vigorous $\mathrm{CD} 8^{+} \mathrm{T}$-lymphocyte response, this still leaves unexplained how activated pp89-specific T cells protect against lethal infection $(16,36)$ if in vivo fibroblasts are refractory to control by these cells. To explain the in vivo function of such $\mathrm{CD}^{+} \mathrm{T}$ lymphocytes, we postulated that the blocking of antigen presentation must be subject to regulation. We observed that incubation of fibroblasts in vitro with conditioned media from $\mathrm{CD}^{+} \mathrm{T}$-lymphocyte cultures prior to MCMV infection rendered them susceptible to attack by pp89-specific CTL. Hypothetically, that could be due to many factors. However, inhibition with antibodies to IFN- $\gamma$ or usage of recombinant IFN- $\gamma$ shows that IFN- $\gamma$ can mediate this effect on its own and that the concentration of locally released IFN- $\gamma$ is sufficient to suggest that similar effects are operative in vivo. Although we cannot exclude the activity of other factors, this cytokine probably represents a major contributor. Support for this conclusion includes the finding that the antiviral $\mathrm{CD} 8^{+} \mathrm{T}$-cell effector function in vivo requires IFN- $\gamma$.

The documented antiviral effect of pp89-specific $\mathrm{T}$ cells in vivo protects against death but not against severe infection (16, 36 ). Since the $\mathrm{CD} 8^{+} \mathrm{T}$-cell function is demonstrated here to be directly dependent on IFN- $\gamma$, it is not surprising that the efficacy of this effector cell population is limited in its capacity to control disseminating virus and to restrict MCMV spreading to new sites of infection where cytokine levels are low.

An initial IFN- $\gamma$ release is required to initiate the presentation of the viral antigen under study. Which are the probable sources of IFN- $\gamma$ ? If we consider $\mathrm{CD}^{+} \mathrm{T}$ lymphocytes as IFN- $\gamma$ producers, some initial MCMV antigen presentation must occur. This is the case because of the constitutive resistance to the $E$ gene effect mentioned above. In addition, MCMV antigens that do not require the effect of IFN- $\gamma$ for presentation, for instance, structural components of the virus introduced into the cell during infection $(8,34)$, exist. The initiation of a protective $\mathrm{CD}^{+} \mathrm{T}$ lymphocyte response can occur in the absence of CD $4^{+} \mathrm{T}$ lymphocytes $(17,33)$. Nevertheless, considering the fully immunocompetent host, $\mathrm{CD} 4^{+} \mathrm{T}$ lymphocytes and NK cells which are activated during the initial steps of MCMV infection by MHC class I-independent mech- anisms are also likely to represent major sources of IFN- $\gamma(5$, 26).

IFN- $\gamma$-treated and subsequently infected cells contain about 25 -fold more naturally processed peptide than untreated cells, yielding approximately $10^{5}$ extractable peptides per cell, which is a significantly higher number than estimates for in vitro virus-infected cells (38). This shows that peptide presentation in vitro and in vivo can differ considerably in quantity. How IFN- $\gamma$ affects processing and peptide transport is at present poorly defined. We focused on MHC class I molecule biosynthesis and transport because it is generally held that the half-life of peptides is short unless complex formation with MHC class I molecules occurs. Therefore, any effect on processing and endoplasmic reticulum transport of peptides only, without affecting MHC class I molecule export, would not have rescued antigen presentation. As far as can be judged by the methods used, the observed increase in MHC class I expression is in good agreement with the increase in the amount of peptides.

We have previously shown that presence of processed viral peptides in cells is not necessarily associated with antigen presentation (7). Because IFN- $\gamma$ rescues presentation, two possibilities existed: either a cessation of the viral effect by interference with the negative factor or an escape from the inhibition by a surplus of peptide-loaded molecules. Although an action of IFN- $\gamma$ on the viral protein cannot be excluded, because the responsible $\mathrm{E}$ phase protein is not yet defined, the data provided the answer that the latter alternative is probably correct. IFN- $\gamma$-treated cells synthesize much greater numbers of class I molecules, and only in these cells is there also sufficient export to the cell surface. Although many molecules were now transported to the cell surface, the viral factor was nevertheless able to retain a major fraction of complexes.

Viruses have evolved different strategies to evade or counteract immune control, such as expression of cytokines, cytokine receptors, or production of enzymes that regulate cytokine function and thus interfere with their function (for a review, see reference 13). This is the first example in which a cytokine can compensate the evasion potential of a virus. The observation that preincubation of at least $12 \mathrm{~h}$ is required to override the viral inhibition does not argue against this role of the cytokine in vivo. The replication cycle of MCMV is slow and takes about $24 \mathrm{~h}$; the replication cycle of human CMV (HCMV) is even more protracted. Thus, if the situation found for the MCMV model also applies for HCMV, cytokines released during a first round of replication could already provide antigen presentation and cause recognition of neighboring cells that are infected during a second round. It is clear, however, that during immunodeficiency, when IFN- $\gamma$ release is low or absent, antigen presentation would remain poor. This view is supported by the finding that neutralization of IFN- $\gamma$ can abrogate the function of adoptively transferred antiviral $\mathrm{CD}^{+} \mathrm{T}$ cells in immunocompromised recipient mice at least in tissues that are critical in MCMV disease, e.g., lungs or adrenal glands. We make the tacit assumption that these mechanisms, like so many others of the MCMV model, also apply to HCMV infection. This would explain the well-known disposition of immunocompromised individuals with deficient IFN- $\gamma$ responses, like AIDS patients (28), to CMV disease (11, 14). Although the HCMV effect on antigen presentation has not been studied, a negative effect has been discussed because HCMV also has a negative effect on MHC class I surface expression (1). On the molecular level, the mechanisms by which HCMV interferes with MHC class I molecules appear different from those of $\operatorname{MCMV}(2,3,7)$, but it will now be of 
interest to see whether IFN- $\gamma$ has an enhancing effect on MHC class I complex formation in HCMV-infected cells.

\section{ACKNOWLEDGMENTS}

We thank T. Hansen for hybridomas secreting MAb directed against $\mathrm{L}^{\mathrm{d}}$ and Matthias $\mathrm{J}$. Reddehase and Margarita del Val for helpful discussion. The skillful technical assistance of Brigitte Reutter and Jutta Späth and the preparation of the manuscript by I. Bennett are greatly appreciated.

This work was supported by the Deutsche Forschungsgemeinschaft (Ko 571 and SFB 322) and the Ministerium für Wirtschaft und Forschung Baden-Württemberg (7532.292-1).

\section{REFERENCES}

1. Barnes, P., and J. E. Grundy. 1992. Down-regulation of the class I HLA heterodimer and $\beta_{2}$-microglobulin on the surface of cells infected with cytomegalovirus. J. Gen. Virol. 73:2395-2403.

2. Browne, H., M. Churcher, and T. Minson. 1992. Construction and characterization of a human cytomegalovirus mutant with the UL18 (class I homolog) gene deleted. J. Virol. 66:6784-6787.

3. Browne, H., G. Smith, S. Beck, and T. Minson. 1990. A complex between the MHC class I homologue encoded by human cytomegalovirus and $\beta_{2}$ microglobulin. Nature (London) 347:770-772.

4. Bühler, B., G. M. Keil, F. Weiland, and U. H. Koszinowski. 1990. Characterization of the murine cytomegalovirus early transcription unit $\mathrm{e} 1$ that is induced by immediate-early proteins. J. Virol. 64:1907-1919.

5. Bukowski, J., J. F. Warner, G. Dennert, and R. M. Welsh. 1985. Adoptive transfer studies demonstrating the antiviral effect of natural killer cells in vivo. J. Exp. Med. 161:40-52.

6. Cobbold, S. P., A. Jayasuriya, A. Nash, T. D. Prospero, and H. Waldmann. 1984. Therapy with monoclonal antibodies by elimination of T-cell subsets in vivo. Nature (London) 328:548-550.

7. Del Val, M., H. Hengel, H. Häcker, U. Hartlaub, T. Ruppert, P. Lučin, and U. H. Koszinowski. 1992. Cytomegalovirus prevents antigen presentation blocking the transport of peptide-loaded major histocompatibility complex class I molecules into the medial-Golgi compartment. J. Exp. Med. 172:729-738.

8. Del Val, M., K. Münch, M. J. Reddehase, and U. H. Koszinowski. 1989. Presentation of cytomegalovirus immediate-early antigens to cytolytic $\mathrm{T}$ lymphocytes is selectively blocked by viral genes expressed in the early phase. Cell 58:305-315.

9. Del Val, M., H.-J. Schlicht, T. Ruppert, M. J. Reddehase, and U. H. Koszinowski. 1991. Efficient processing of an antigenic sequence for presentation by MHC class I molecules depends on its neighboring residues in the protein. Cell 66:1145-1153.

10. Del Val, M., H. Volkmer, J. B. Rothbard, S. Jonjić, M. Messerle, J. Schickedanz, M. J. Reddehase, and U. H. Koszinowski. 1988. Molecular basis for cytolytic T-lymphocyte recognition of the murine cytomegalovirus immediate early protein pp89. J. Virol. 62:3965-3972.

11. Drew, W. L., and L. Mintz. 1984. Cytomegalovirus infection in healthy and immune-deficient homosexual men, p. 117-123. In P. Ma and D. Armstrong (ed.), The acquired immune deficiency syndrome and infections of homosexual men. Yorke Medical Books, New York.

12. Echtenacher, B., W. Falk, D. N. Mannel, and P. H. Krammer. 1990. Requirement of endogenous tumor necrosis factor/cachectin for recovery from experimental peritonitis. J. Immunol. 145:37623768.

13. Gooding, L. R. 1992. Virus proteins that counteract host immune defense. Cell 71:5.

13a.Hengel, $\mathbf{H}$. Unpublished data.

14. Ho, M. 1982. Human cytomegalovirus infections in immunosuppressed patients, p. 171-204. In W. B. Greenough and T. C. Merrigan (ed.), Cytomegalovirus, biology and infection: current topics in infectious disease. Plenum Press, New York.

15. Hsu, V. W., L. C. Yuan, J. G. Nuchtern, J. Lippincott-Schwartz, G. J. Hämmerling, and R. D. Klausner. 1991. A recycling pathway between the endoplasmic reticulum and the Golgi apparatus for retention of unassembled MHC class I molecules. Nature (London) 352:441-444.
15a.Jonjić, S. Unpublished data.

16. Jonjić, S., M. Del Val, G. M. Keil, M. J. Reddehase, and U. H. Koszinowski. 1988. A nonstructural viral protein expressed by a recombinant vaccinia virus protects against lethal cytomegalovirus infection. J. Virol. 62:1653-1658.

17. Jonjić, S., W. Mutter, F. Weiland, M. J. Reddehase, and U. H. Koszinowski. 1989. Site-restricted persistent cytomegalovirus infection after selective long-term depletion of $\mathrm{CD}^{+} \mathrm{T}$ lymphocytes. J. Exp. Med. 169:1199-1212.

18. Kelly, A., S. H. Powis, R. Glynne, E. Radley, S. Beck, and J. Trowsdale. 1991. Second proteasome-related gene in the human MHC class II region. Nature (London) 353:667-668.

19. Klar, D., and G. J. Hämmerling. 1989. Induction of assembly of MHC class I heavy chains with $\beta_{2}$ microglobulin by interferon- $\gamma$. EMBO J. 8:475-481.

20. Kornfeld, R., and S. Kornfeld. 1985. Assembly of asparaginelinked oligosaccharides. Annu. Rev. Biochem. 54:631-664.

21. Koszinowski, U. H., M. Del Val, and M. J. Reddehase. 1990. Cellular and molecular basis of the protective immune response to cytomegalovirus infection. Curr. Top. Microbiol. Immunol. 154: 189-220.

22. Kvist, S., and U. Hamann. 1990. A nucleoprotein peptide of influenza A virus stimulates assembly of HLA-B27 class I heavy chains and $\beta_{2}$-microglobulin translated in vitro. 1990. Nature (London) 348:446-448.

23. Levy, F., R. Gabathuler, R. Larsson, and S. Kvist. 1991. ATP is required for in vitro assembly of MHC class I antigens but not for transfer of peptides across the ER membrane. Cell 67:265-274.

24. Lie, W.-R., N. B. Myers, J. M. Connolly, J. Gorka, D. R. Lee, and T. H. Hansen. 1991. The specific binding of peptide ligand to $\mathbf{L}^{d}$ class I major histocompatibility complex molecules determines their antigenic structure. J. Exp. Med. 173:449-459.

25. Lie, W.-R., N. B. Myers, J. Gorka, R. J. Rubocki, J. M. Connolly, and T. H. Hansen. 1990. Peptide ligand induced conformation and surface expression of the $\mathrm{L}^{\mathrm{d}}$ class I MHC molecule. Nature (London) 344:439-441.

26. Lučin, P., I. Pavić, B. Polić, S. Jonjić, and U. H. Koszinowski. 1992. Gamma interferon-dependent clearance of cytomegalovirus infection in salivary glands. J. Virol. 66:1977-1984.

27. Martinez, C. K., and J. J. Monaco. 1991. Homology of proteasome subunits to a major histocompatibility complex-linked LMP gene. Nature (London) 353:664-667.

28. Murray, H., B. Rubin, H. Masur, and R. B. Roberts. 1984 Impaired production of lymphokines and immune (gamma) interferon in the acquired immunedeficiency syndrome. N. Engl. J. Med. 310:883-888.

29. Ortiz-Navarrete, V., A. Seelig, M. Gernold, S. Frentzel, P. M. Kloetzel, and G. J. Hämmerling. 1991. Subunit of the 20s proteasome (multicatalytic proteinase) encoded by the major histocompatibility complex. Nature (London) 353:662-664.

30. Pestka, S., J. A. Langer, K. C. Zoon, and C. E. Samuel. 1987 Interferons and their actions. Annu. Rev. Biochem. 56:727-777.

31. Powis, S., A. R. M. Townsend, E. V. Deverson, J. Bastin, G. W. Butcher, and J. C. Howard. 1991. Restoration of antigen presentation to the mutant cell line RMA-S by an MHC-linked transporter. Nature (London) 354:528-531.

32. Prat, M., G. Gribaudo, P. M. Comoglio, G. Cavallo, and S. Landolfo. 1984. Monoclonal antibodies against murine $\gamma$ interferon. Proc. Natl. Acad. Sci. USA 81:4515-4519.

33. Reddehase, M. J., S. Jonjić, F. Weiland, W. Mutter, and U. H. Koszinowski. 1988. Adoptive immunotherapy of murine cytomegalovirus adrenalitis in the immunocompromised host: CD4-helperindependent antiviral function of CD8-positive memory T lymphocytes derived from latently infected donors. J. Virol. 62:1061-1065.

34. Reddehase, M. J., G. M. Keil, and U. H. Koszinowski. 1984. The cytolytic T lymphocyte response to the murine cytomegalovirus II. Detection of virus replication stage-specific antigens by separate populations of in vivo active cytolytic $\mathrm{T}$ lymphocyte precursors. Eur. J. Immunol. 14:56-61.

35. Reddehase, M. J., and U. H. Koszinowski. 1984. Significance of herpesvirus immediate early gene expression in cellular immunity to cytomegalovirus infection. Nature (London) 312:369-371.

36. Reddehase, M. J., W. Mutter, K. Münch, H.-J. Bühring, and U. H. 
Koszinowski. 1987. CD8-positive T lymphocytes specific for murine cytomegalovirus immediate-early antigens mediate protective immunity. J. Virol. 61:3102-3108.

37. Reddehase, M. J., F. Weiland, K. Münch, S. Jonjic, A. Lüske, and U. H. Koszinowski. 1985. Interstitial murine cytomegalovirus pneumonia after irradiation: characterization of cells that limit viral replication during established infection of the lungs. J. Virol. 55:264-273.

38. Rötzschke, O., K. Falk, K. Deres, H. Schild, M. Norda, J. Metzger, G. Jung, and H.-G. Rammensee. 1990. Isolation and analysis of naturally processed viral peptides as recognized by cytotoxic $\mathrm{T}$ cells. Nature (London) 348:252-254.

39. Sibille, C., K. Gould, G. Hämmerling, and A. Townsend. 1992. A defect in the presentation of intracellular viral antigens is restored by interferon- $\gamma$ in cell lines with impaired major histocompatibility complex class I assembly. Eur. J. Immunol. 22:433-440.

40. Smith, J. D., W.-R. Lie, J. Gorka, C. S. Kindle, N. B. Myers, and T. H. Hansen. 1992. Disparate interaction of peptide ligand with nascent versus mature class I major histocompatibility complex molecules: comparisons of peptide binding to alternative forms of $\mathrm{L}^{\mathrm{d}}$ in cell lysates and the cell surface. J. Exp. Med. 175:191-202.

41. Spies, T., M. Bresnahon, S. Bahram, D. Arnold, G. Blanck, E. Mellus, D. Pious, and R. DeMars. 1990. A gene in the human major histocompatibility complex class II region controlling the class I antigen presentation pathway. Nature (London) 348:744 747.

42. Townsend, A., and H. Bodmer. 1989. Antigen recognition by class I-restricted T lymphocytes. Annu. Rev. Immunol. 7:601-624.

43. Townsend, A., T. Elliott, V. Cerundolo, L. Foster, B. Barber, and A. Tse. 1990. Assembly of MHC class I molecules analyzed in vitro. Cell 62:285-295.

44. Wong, G. H. W., I. Clark-Lewis, J. L. McKimm-Breschkin, A. W. Harris, and J. W. Schrader. 1983. Interferon- $\gamma$ induces enhanced expression of Ia and $\mathrm{H}-2$ antigens on B lymphoid, macrophage, and myeloid cell lines. J. Immunol. 131:788-793. 